\title{
Mapping of SrTm4, a Recessive Stem Rust Resistance Gene from Diploid Wheat Effective to Ug99
}

\author{
Jordan Briggs, Shisheng Chen, Wenjun Zhang, Sarah Nelson, Jorge Dubcovsky, and Matthew N. Rouse
}

\begin{abstract}
First, fourth, and sixth authors: Department of Plant Pathology, University of Minnesota, St. Paul 55108; second, third, and fifth author: Department of Plant Sciences, University of California, Davis 95616; second author: Triticeae Research Institute, Sichuan Agricultural University, Wenjiang, Chengdu, Sichuan, 611130, P.R. China; fifth author: Howard Hughes Medical Institute, Chevy Chase, MD 20815; and sixth author: USDA-ARS Cereal Disease Laboratory, St. Paul, MN 55108.

Accepted for publication 29 March 2015.
\end{abstract}

\begin{abstract}
Briggs, J., Chen, S., Zhang, W., Nelson, S., Dubcovsky, J., and Rouse, M. N. 2015. Genetic mapping of $S r T m 4$, a recessive stem rust resistance gene from diploid wheat effective to Ug99. Phytopathology 105:1347-1354.

Race TTKSK (or Ug99) of Puccinia graminis f. sp. tritici, the causal agent of wheat stem rust, is a serious threat to wheat production worldwide. Diploid wheat, Triticum monococcum (genome $\mathrm{A}^{\mathrm{m}}$ ), has been utilized previously for the introgression of stem rust resistance genes $S r 21$, Sr22, and Sr35. Multipathotype seedling tests of biparental populations demonstrated that T. monococcum accession PI 306540 collected in Romania contains a recessive resistance gene effective

to all $P$. graminis f. sp. tritici races screened, including race TTKSK. We will refer to this gene as $\operatorname{SrTm} 4$, which is the fourth stem rust resistance gene characterized from T. monococcum. Using two mapping populations derived from crosses of PI $272557 \times$ PI 306540 and G3116 × PI 306540, we mapped SrTm4 on chromosome arm $2 \mathrm{~A}^{\mathrm{m} L}$ within a $2.1 \mathrm{cM}$ interval flanked by sequence-tagged markers $B Q 461276$ and $D R 732348$, which corresponds to a $240-\mathrm{kb}$ region in Brachypodium chromosome 5. The eight microsatellite and nine sequence-tagged markers linked to $\mathrm{SrTm} 4$ will facilitate the introgression and accelerate the deployment of $\mathrm{SrTm} 4$-mediated Ug99 resistance in wheat breeding programs.
\end{abstract}

Over 700 million metric tons of wheat, Triticum aestivum L. and T. turgidum ssp. durum (Desf.) Husn., are produced worldwide each year (FAO 2013), playing an important role in global food security. Reducing yield losses to pests and pathogens is critical to maintain and increase wheat productivity. Historically, stem rust has produced large yield losses, which can exceed 50\% in susceptible wheat cultivars during Puccinia graminis f. sp. tritici epidemics (Leonard 2001; Roelfs 1978). Breeding efforts to increase genetic resistance to stem rust, development of early maturing varieties, and efforts to remove the alternate host Berberis vulgaris L. near wheatgrowing regions provided significant control of $P$. graminis $\mathrm{f}$. $\mathrm{sp}$. tritic $i$ in the past and reduced both severity and incidence of the stem rust disease (Peterson et al. 2005; Roelfs 1982, 1985). However, the emergence of the $P$. graminis f. sp. tritici $\mathrm{Ug} 99$ race group, composed of race TTKSK and variant races, allowed $P$. graminis f. sp. tritici to overcome many of the deployed stem rust resistance genes, making $P$. graminis f. sp. tritici again a threat to wheat production worldwide (Pretorius et al. 2000; Singh et al. 2011). The adaptation of the $\mathrm{Ug} 99$ race group to previously resistant cultivars has rendered three resistance genes $(\mathrm{Sr} 24, \mathrm{Sr} 36, \mathrm{Sr} 9 \mathrm{~h})$ ineffective since the initial characterization of race TTKSK (Jin et al. 2008, 2009; Pretorius et al. 2012; Rouse et al. 2014), although these three genes remain effective against many $P$. graminis $\mathrm{f}$. sp. tritici races. Over 50 wheat stem rust resistance genes have been identified (McIntosh et al. 1995, 2013), yet few of the ones present in current

Corresponding author: M. N. Rouse; E-mail address: matthew.rouse@ars.usda.gov

The first two authors contributed equally to this work.

*The $\boldsymbol{e}$-Xtra logo stands for "electronic extra" and indicates that one supplementary table is published online.

http://dx.doi.org/10.1094/PHYTO-12-14-0382-R

This article is in the public domain and not copyrightable. It may be freely reprinted with customary crediting of the source. The American Phytopathological Society, 2015 commercial wheat varieties are effective to the Ug99 race group (Jin and Singh 2006; Sharma et al. 2013; Singh et al. 2011).

Wheat wild relatives at different ploidy levels have been previously utilized for introgressing resistance genes effective against stem rust into cultivated varieties including $\mathrm{Sr} 21, \mathrm{Sr} 22$, and $\mathrm{Sr} 35$ from T. monococcum L. (Gerechter-Amitai et al. 1971; McIntosh et al. 1984; The 1973); Sr33, Sr45, Sr46, SrTA10171, SrTA10187, and SrTA1662 from A. tauschii Coss. (Kerber and Dyck 1979; Marais et al. 1998; McIntosh et al. 2013; Olson et al. 2013a,b); Sr32, Sr39, and $\mathrm{Sr} 47$ from A. speltoides Tausch (Faris et al. 2008; Kerber and Dyck 1990; McIntosh et al. 1995); and Sr36, Sr37, and Sr40 from T. timopheevii (Zhuk.) Zhuk. (Dyck 1992; McIntosh and Gyarfas 1971). Among these resistance genes only Sr35 and Sr33 have been cloned and both encode nucleotide-binding-site leucine-rich repeat proteins (NB-LRR) (Periyannan et al. 2013; Saintenac et al. 2013).

This study focused on a resistance gene from T. monococcum, a species closely related to T. urartu, the donor of the A genome to the polyploid wheat species. T. monococcum and T. urartu are endemic to the same geographic regions, have identical karyotypes (Giorgi and Bozzini 1969), and have normal bivalent chromosome pairing in meiosis (Dvorak 1976; Nath et al. 1984), but their hybrids are sterile confirming that they are different species (Johnson and Dhaliwal 1976). The DNA sequences of these diploid species are sufficiently differentiated to greatly reduce paring between the T. monococcum chromosomes and the A genome chromosomes from polyploid wheat when they are in the presence of the wild-type Paring homeologous 1 (Phl) gene (Dubcovsky et al. 1995; Luo et al. 1996).

The T. monococcum ssp. monococcum accession PI 306540 was identified in a previous study as possessing potentially new resistance genes based on seedling ITs to $P$. graminis $\mathrm{f}$. sp. tritici races (Rouse and Jin 2011b). $\mathrm{F}_{2: 3}$ families derived from a cross between PI 306540 and stem rust susceptible $T$. monococcum ssp. monococcum PI 272557 were screened with race TTKSK and Sr21-virulent races QFCSC and TTTTF. Segregation of resistance to race TTKSK indicated the presence of three resistance genes 
(Rouse and Jin 2011a). One of the three genes was predicted to be $S r 21$. The other two genes are different from T. monococcum known resistance genes $S r 22$ and $S r 35$ (Rouse and Jin 2011a). One of these two genes was effective to $P$. graminis $\mathrm{f}$. sp. tritici races TTKSK and QFCSC, but ineffective to race TTTTF. The other gene we refer to as SrTm4 produced a mesothetic (intermediate reaction with both resistant and susceptible ITs present) IT when present singly (Rouse and Jin 2011a). In a population derived from PI 306540, a low or mesothetic reaction was observed in environmentally controlled settings to races QFCSC and TTKSK in families predicted to carry $S r T m 4$ based on the presence of a mesothetic IT to race TTTTF. The objective of this study was to genetically map $\operatorname{SrTm} 4$, to identify the colinear regions in other sequenced genomes, and to develop molecular markers closely linked to the gene that can be effectively used to monitor the introgression of a small segment of T. monococcum chromosome $2 \mathrm{~A}^{\mathrm{m}}$ carrying $\operatorname{SrTm} 4$ into common wheat.

\section{MATERIALS AND METHODS}

Plant materials. Two $\mathrm{F}_{2}$ mapping populations, including 89 individuals from the cross of PI $272557 \times$ PI 306540 and 190 individuals from the cross of G3116 × PI 306540, were used to map SrTm4 in diploid wheat. PI 306540 and PI 272557 are cultivated spring T. monococcum ssp. monococcum accessions obtained from the U.S. Department of Agriculture (USDA) National Small Grains Collection. PI 272557 was characterized as susceptible to five races of $P$. graminis f. sp. tritici in a previous study (Rouse and Jin 2011b). G3116 (PI 427992) is a wild T. monococcum ssp. aegilopoides and was selected as a parent of the second cross because of its high level of polymorphism compared with cultivated T. monococcum ssp. monococcum (Dubcovsky et al. 1996). Based on seedling tests with multiple $P$. graminis f. sp. tritici races, G3116 was postulated to possess resistance gene $S r 21$ (Zhang et al. 2010). This hypothesis was confirmed in a recent study that mapped the $S r 21$ resistance from G3116 to the long arm of chromosome $2 \mathrm{~A}^{\mathrm{m}}$, roughly $50 \mathrm{cM}$ from the centromere (Chen et al. 2015). Since both G3116 and PI 306540 carry $S r 21$, a $P$. graminis f. sp. tritici race virulent to $S r 21$ (e.g., TTTTF) was used to map $S r T m 4$ in this population. The Swiss winter wheat cultivar Arina (obtained from the Australian Winter Cereals Collection, Tamworth, AUS-21732) was utilized as a check line for $\mathrm{Sr} 48$ in some of our experiments.

Evaluation of stem rust resistance. Inoculation of seedlings with P. graminis f. sp. tritici isolates was performed at the USDAAgricultural Research Service (USDA-ARS) Cereal Disease Laboratory according to previously described methods (Rouse et al. 2011). P. graminis f. sp. tritici race TTTTF (isolate 01MN84A-1-2) was used to inoculate the parents and 25 individuals from each $\mathrm{F}_{2: 3}$ family. At least two replications were performed for each $\mathrm{F}_{2: 3}$ family. After inoculation, plants were incubated in growth chambers maintained at $18^{\circ} \mathrm{C}$ day, $15^{\circ} \mathrm{C}$ night with a $16 \mathrm{~h}$ photoperiod. The lower incubation temperature was necessary to ensure consistent expression of SrTm4 resistance. Infection types (ITs) were assessed 14 days after inoculation on the primary leaves using a 0 to 4 scale described by Stakman et al.
(1962). ITs of 2 and less including mesothetic $(; 3,13$, or ;23) ITs denote resistant reactions and ITs of 3 and greater denote susceptible reactions. The $\mathrm{F}_{2} \mathrm{SrTm} 4$ genotypes were based on the phenotypes of their $\mathrm{F}_{2: 3}$ families and classified as homozygous resistant (HR), heterozygous (Het), or homozygous susceptible (HS).

We also inoculated PI 306540, PI 272557, G3116, Einkorn (PI 10474), and wheat cultivar Arina with diverse $P$. graminis f. sp. tritici races that are virulent on $S r 21$ including TTTTF, TPMKC, RKQQC, RCRSC, QTHJC, QFCSC, and SCCSC (isolates 01MN84A-1-2, 74MN1409, 99KS76A, 77ND82A, 75ND717C, 06ND76C, and 09ID73-2) to determine the effectiveness of SrTm4 to different $P$. graminis f. sp. tritici races. The five lines were also inoculated with $\mathrm{Sr} 21$-avirulent race MCCFC (isolate 59KS19). Presence of ITs characteristic of $\operatorname{SrTm} 4$ (IT ;3, 13, or ;23) were considered indicative of the effectiveness of $\operatorname{SrTm} 4$ to each $P$. graminis f. sp. tritici race.

Molecular marker analyses. Genomic DNA from the $F_{2: 3}$ families was bulk extracted using a modified CTAB protocol (Yu et al. 2008) from a minimum of $10 \mathrm{~F}_{2: 3}$ plants per family. Single sequence repeats (SSR) markers were selected to screen for polymorphism in regions associated with $\mathrm{SrTm} 4$ using protocols described before (Röder et al. 1998; Somers et al. 2004; Song et al. 2005). Wheat ESTs that were previously mapped to the long arm of chromosome $2 \mathrm{~A}$ were also tested for sequence polymorphism to develop sequence-based markers. ESTs linked to $S r T m 4$ were then used to search for the orthologous region in the Brachypodium genome. Brachypodium genes found in the targeted region were then used to find wheat orthologs and to develop new markers.

Genetic mapping. The linkage map of $\mathrm{SrTm} 4$ was constructed using MapMaker version 3.0b (Lander et al. 1987). The Kosambi mapping function was used to calculate map distances. The genetic linkage map was drawn with the software MapDraw V2.1 (Liu and Meng 2003).

\section{RESULTS}

Evaluation of SrTm4 resistance. PI 306540 displayed resistant ITs characteristic of SrTm4 to all of the P. graminis f. sp. tritici races tested (Table 1; Figs. 1 and 2). The ITs of G3116 and PI 10474 were consistent with the presence of $\operatorname{Sr} 21$ in these lines (Table 1). PI 272557 was susceptible to all of the $P$. graminis $\mathrm{f} . \mathrm{sp}$. tritici races and wheat cultivar Arina was resistant to all of the races.

ITs in resistant $\mathrm{F}_{2: 3}$ families derived from the PI $272557 \times$ PI 306540 cross ranged from ; 3 to 31 , whereas susceptible families exhibited ITs ranging from 3 to 4 in response to race TTTTF (Fig. 1). Among the $89 \mathrm{~F}_{3}$ families, we detected 11 homozygous resistant, 49 segregating for resistance, and 29 homozygous susceptible. This ratio deviated slightly from the expected 1:2:1 segregation ratio $\left(\chi^{2}=8.19\right.$, $P=0.017)$. However, the segregation of resistance among 1,370 plants from the progeny of the 49 segregating $\mathrm{F}_{2: 3}$ families was 346 resistant plants and 1,024 susceptible, which fit a 1:3 segregation ratio expected for a single recessive resistance gene $\left(\chi^{2}=0.048, P=0.82\right)$.

ITs in resistant $F_{2: 3}$ families derived from the G3116 × PI 306540 cross ranged from $; 3$ to 31 , whereas susceptible families exhibited

TABLE 1. Infection types of Triticum monococcum lines and wheat cultivar Arina to selected races of Puccinia graminis f. sp. tritici

\begin{tabular}{|c|c|c|c|c|c|}
\hline \multirow[b]{2}{*}{ P. graminis f. sp. tritici race } & \multicolumn{5}{|c|}{ Line } \\
\hline & PI 306540 & PI 272557 & G3116 & PI 10474 & Arina \\
\hline TTTTF & $; 13$ & $33+$ & 3 & $33+$ & 13-LIF \\
\hline TPMKC & ; & $33+$ & 3 & $33+$ & 13-LIF \\
\hline RKQQC & $; 13$ & $33+$ & 3 & 3 & $13-$ \\
\hline RCRSC & ;13 & $33+$ & 3 & $33+$ & 3-LIF \\
\hline QTHJC & $; 12+$ & $33+$ & 3 & $33+$ & 13-LIF \\
\hline QFCSC & $; 1$ & $33+$ & 3 & $33+$ & 13-LIF \\
\hline SCCSC & ;13 & $33+$ & 3 & $33+$ & 13-LIF \\
\hline MCCFC & $; 1$ & $33+$ & $; 1$ & $; 1$ & 3-LIF \\
\hline
\end{tabular}


ITs ranging from 3 to 4 in response to race TTTTF. Among the $190 \mathrm{~F}_{2: 3}$ families analyzed for this population, we detected 39 homozygous resistant families, 108 families segregating for resistance to race TTTTF, and 43 homozygous susceptible families. This ratio did not deviate significantly from the expected 1:2:1 segregation ratio expected for a single gene $\left(\chi^{2}=3.72, P=0.155\right)$. Analysis of 1,318 plants from the progeny of 60 segregating $\mathrm{F}_{2: 3}$ families in this population resulted in $363(27.5 \%)$ resistant plants and $955(72.5 \%)$ susceptible plants, which is close to the $1: 3$ segregation ratio expected for a single recessive resistance gene $\left(\chi^{2}=4.54, P=0.033\right)$.

Identification of SSR markers linked with SrTm4. Bulked segregant analysis (BSA) was used to identify SSR markers linked with $S r T m 4$. Among the initial polymorphic SSR markers tested in population PI $272557 \times$ PI 306540, gwm265 showed significant linkage to SrTm4. Marker gwm265 was previously mapped to chromosome arm 2AL in wheat (Röder et al. 1998; Song et al. 2005). Therefore, additional SSR markers from 2AL were screened on the parents for polymorphisms and all polymorphic markers were screened on the $\mathrm{F}_{2: 3}$ population. A total of seven SSR markers in population PI $272557 \times$ PI 306540 and six SSR markers in population G3116 × PI 306540 were found to be linked with $\operatorname{SrTm} 4$ (Fig. 3; Table 2).

Development of sequenced-based markers linked to SrTm4. To saturate the chromosome region carrying $\operatorname{SrTm} 4$ and to identify the collinear region in other cereal genomes like Brachypodium, we selected several wheat ESTs from the long arm of chromosome 2A to develop sequence based markers. Wheat EST BG313738 was found to be polymorphic in both populations and was mapped proximal to $S r T m 4$. The sequence of $B G 313738$ was used to identify a colinear region in chromosome 5 of Brachypodium where we selected thirty genes to develop additional markers for SrTm4. These efforts resulted in two additional sequence-tagged markers in the PI $272557 \times$ PI 306540 population and eight in the G3116 × PI 306540 population linked with $\operatorname{SrTm} 4$ (Fig. 3; Table 2). The two closest markers flanking $S r T m 4$ were $B Q 461276$ (1.6 cM proximal to SrTm4) and DR732348 (0.5 cM distal to SrTm4, Fig. 2), which defined a $2.1 \mathrm{cM}$ candidate region for SrTm4 in the G3116 $\times$ PI 306540 population. Marker DR732348 was developed from the same contig as SSR markers $g w m 526$ and $g d m 93$, which amplify the same SSR locus. The flanking SSR sequences were used to identify the T. aestivum contig (IWGSC_2AL_contig 6401556, The International Wheat Genome Sequencing Consortium 2014), and then a gene within this contig was used to develop marker DR732348.

SrTm4 colinear region in Brachypodium. The proximal marker $B Q 461276$ was identified to be orthologous to Brachypodium gene Bradi5g25720 (Bd5: 26,907,758 bp to 26,910,587 bp), whereas the distal marker $D R 732348$ was $91 \%$ identical at the DNA level with Bradi5g26020 (Bd5: 27,127,725 bp to 27,147,892 bp) (Fig. 2C). The SrTm4 flanking markers define a $240-\mathrm{kb}$ genomic region in Brachypodium chromosome 5 (Bd5: 26,907,758 bp to $27,147,892 \mathrm{bp})$ that includes 29 putative Brachypodium genes (Bradi5g25730 to Bradi5g26010). The functional annotation of these 29 genes (Supplementary Table S1) does not include any NBLRR resistance genes.

The relative map position of $\mathrm{SrTm} 4$ with other $\mathrm{Sr}$ genes on chromosome 2AL. Two previously characterized wheat stem rust resistance genes, $\operatorname{Sr} 21$ and $\mathrm{Sr} 48$, have been mapped before on chromosome arm 2AL (Bansal et al. 2008, 2009; Chen et al. 2015). Sr21 was mapped roughly $50 \mathrm{cM}$ from the centromere and $29.1 \mathrm{cM}$ proximal to marker BG313738, whereas SrTm4 was mapped $5.8 \mathrm{cM}$ distal to the same sequence-tagged marker and $\sim 85 \mathrm{cM}$ from the centromere. This result clearly indicates that $\mathrm{SrTm} 4$ and $\mathrm{Sr} 21$ are two different loci, located $\sim 35$ cM apart (Fig. 4).

Sr48 has been previously mapped $22.1 \mathrm{cM}$ distal to marker gwm382 (Bansal et al. 2008, 2009; Fig. 3B) on the long arm of chromosome $2 \mathrm{~A}$ from 'Arina'. Initially, no common markers were available between the $S r 48$ and SrTm4 maps, complicating the comparative analysis. To generate a common reference point, we first sequenced the PCR product of gwm382 and identified T. aestivum contig IWGSC_2AL_contig 6435092 (The International Wheat Genome Sequencing Consortium 2014) that includes the gwm382 SSR flanking sequences. From this contig we developed marker $B G 907495$ that was mapped $11.7 \mathrm{cM}$ distal to SrTm4. Based on these distances, SrTm4 is located $29.9 \mathrm{cM}$ proximal to $\mathrm{Sr} 48$ (Fig. 4).

\section{DISCUSSION}

A previous survey of $T$. monococcum for resistance to Ug99 (Rouse and Jin 2011b) postulated that most of the resistant accessions carry the mapped genes Sr21 (Chen et al. 2015), Sr22 (Periyannan et al. 2011),

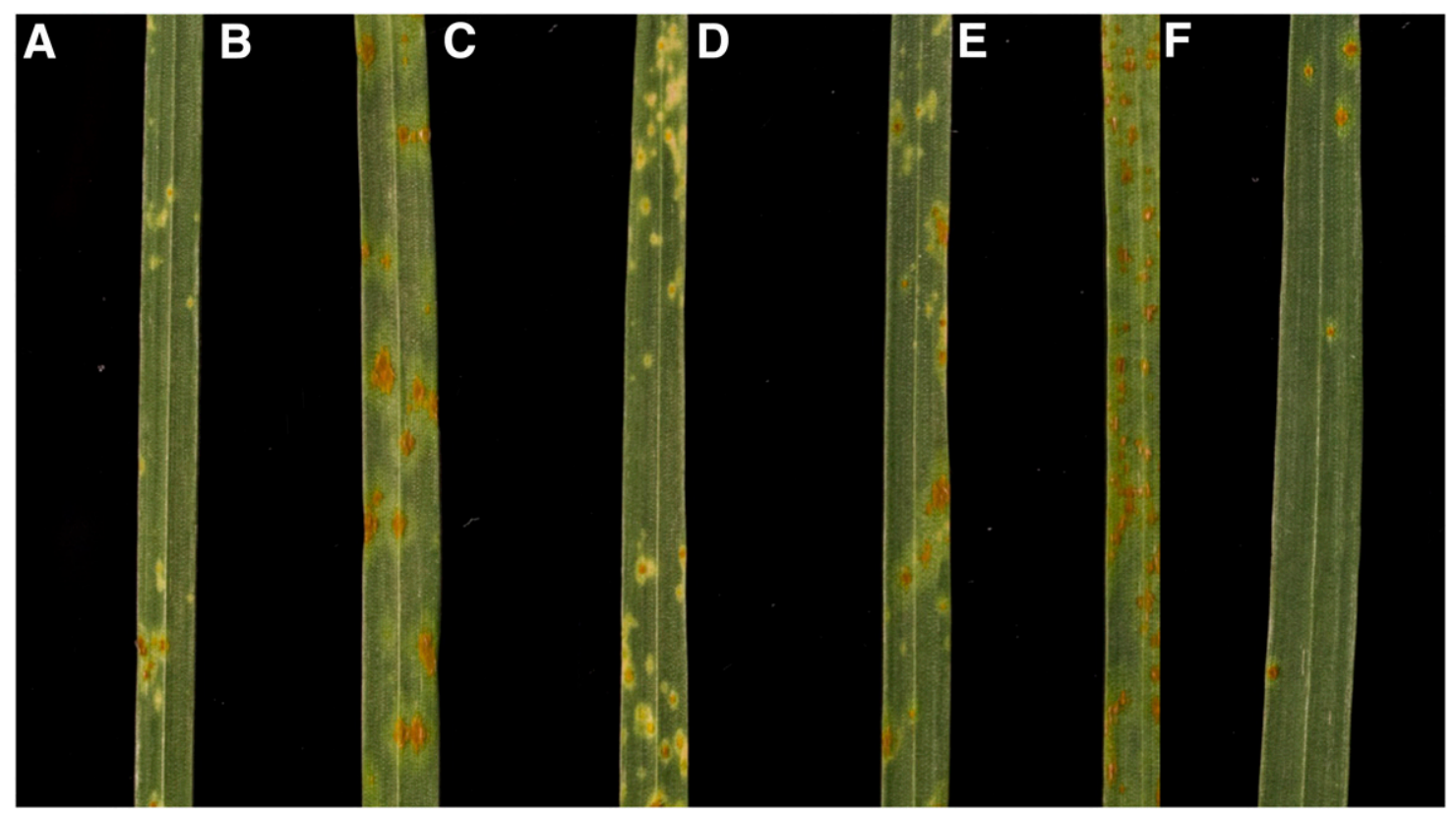

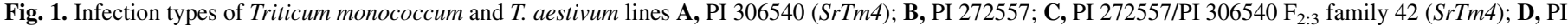
272557/PI $306540 \mathrm{~F}_{2: 3}$ family 70 (SrTm4); E, PI 10474 (Sr21); and F, Arina (Sr48) in response to physiologic race TTTTF of Puccinia graminis f. sp. tritici. 
or Sr35 (Saintenac et al. 2013). However, accession PI 306540, a cultivated T. monococcum ssp. monococcum collected in Romania, possessed two different resistance genes (Rouse and Jin 2011a).

We focused on one of these genes, namely $\operatorname{SrTm} 4$, that is effective to the virulent race TTTTF because of the interesting recessive nature of the resistance and its broad resistance to all the $P$. graminis f. sp. tritici races tested so far. The initial study showed that $\mathrm{SrTm} 4$ confers resistance to Ug99 race TTKSK, and additional races TTTTF, TRTTF, QFCSC, and MCCFC (Rouse and Jin 2011a). We showed here that PI 306540 also displayed mesothetic resistant ITs to five additional races that are virulent on Sr21 (TPMKC, RKQQC, RCRSC, QTHJC, and SCCSC) (Fig. 2). The mesothetic type of resistance observed to these races suggests that $\mathrm{SrTm} 4$ is effective to these races. Though the presence of ITs characteristic of a particular gene is not necessarily diagnostic of the presence of that gene, the presence of the mesothetic ITs provides preliminary evidence of the spectrum of effectiveness of SrTm4. The broad-spectrum resistance of SrTm4 makes it a valuable resource for breeding resistance to $\mathrm{Ug} 99$ and other virulent $P$. graminis f. sp. tritici races. However, SrTm4 only confers partial resistance and therefore it should be deployed in combination with other $P$. graminis f. sp. tritici resistance to achieve economically useful levels of resistance.

We have initiated the introgression of SrTm4 from PI 306540 into polyploid wheat. These crosses require the use of a tetraploid bridge because direct crosses between T. monococcum and hexaploid wheat are frequently sterile.
When the complete T. monococcum complement is present, some recombination is observed between the T. monococcum and the A genome chromosomes, but that recombination is reduced to very low levels when only single chromosomes or chromosome pieces of T. monococcum are present in hexaploid wheat (Dubcovsky et al. 1995, Luo et al. 1996). Fortunately, recombination between the A and $\mathrm{A}^{\mathrm{m}}$ chromosomes is restored to normal levels in the presence of the phlb mutation (Dubcovsky et al. 1995). Using the phlb mutation and the multiple markers linked to $\operatorname{SrTm} 4$ developed in this study, it will be possible to engineer a small T. monococcum introgression carrying only $\operatorname{SrTm} 4$.

$\mathrm{Sr} 21$ and $\mathrm{SrTm} 4$ present very different resistance profiles that suggest that they are different genes. Resistance conferred by $\mathrm{Sr} 21$ is dominant, ineffective at lower temperatures $\left(16^{\circ} \mathrm{C}\right)$, and ineffective to several $P$. graminis f. sp. tritici races (TTTTF, QFCSC, TPMKC, RKQQC, RCRSC, QTHJC, and SCCSC). By contrast, resistance conferred by $\mathrm{SrTm} 4$ is recessive, effective at lower temperatures, and screening data suggest $\operatorname{SrTm} 4$ is effective against all $10 P$. graminis f. sp. tritici races tested so far, including several that are virulent on $S r 21$ (e.g., TTTTF). The genetic map of $\mathrm{SrTm} 4$ presented here confirmed that this gene is different from Sr21, and that the two genes are roughly $38 \mathrm{cM}$ apart (Fig. 4) (Chen et al. 2015).

The relationship of $S r T m 4$ and $S r 48$ is not as clear as the relationship between $\mathrm{SrTm} 4$ and $\mathrm{Sr} 21$ described above. $\mathrm{Sr} 48$ was mapped to chromosome arm 2AL of the bread wheat cultivar Arina (Bansal et al. 2008), and was first designated as SrAnl

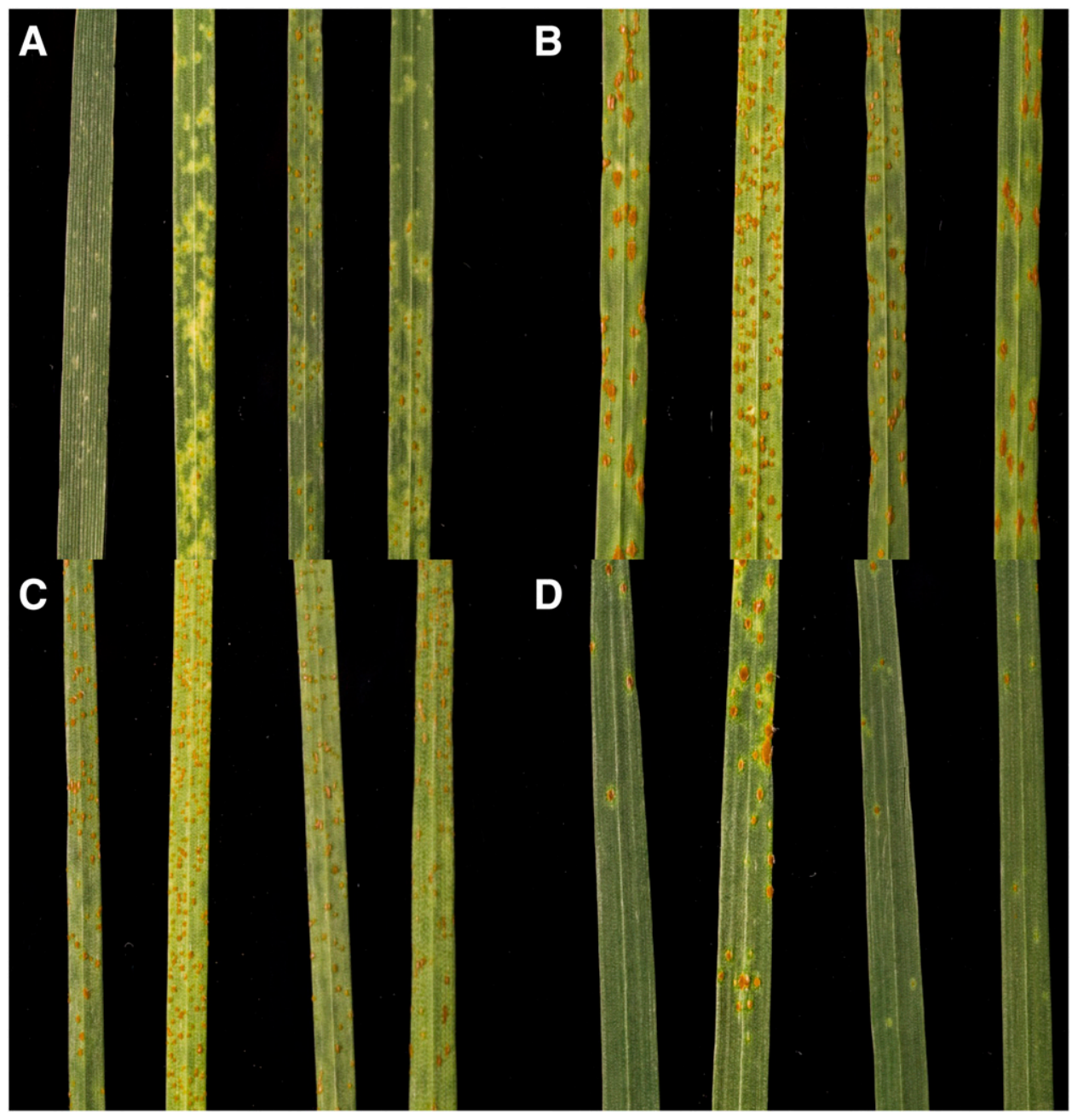

Fig. 2. Infection types of Triticum monococcum and T. aestivum lines A, PI 306540 ( $\operatorname{SrTm} 4)$; B, PI 272557; C, G3116 (Sr21); and D, Arina (Sr48) in response to physiologic races of Puccinia graminis f. sp. tritici: TPMKC, RKQQC, RCRSC, and SCCSC (from left to right within each frame). 
using Australian P. graminis f. sp. tritici isolates 98-1,2,3,5,6 and 34-1,2,7+Sr38. Subsequent mapping placed $\operatorname{Sr} 4816.5 \mathrm{cM}$ distal to the stripe rust resistance locus $\mathrm{Yrl}$ (Bansal et al. 2009). A comparative analysis of shared marker $g w m 382$ (BG907495, is from the same contig as gwm382) between the T. monococcum $2 \mathrm{~A}^{\mathrm{m}}$ genetic map in our present study and the hexaploid wheat $2 \mathrm{~A}$ genetic map (Bansal et al. 2009) indicates SrTm4 is located approximately $30 \mathrm{cM}$ proximal to $\operatorname{Sr} 48$ (Fig. $3 \mathrm{~A}$ and B).

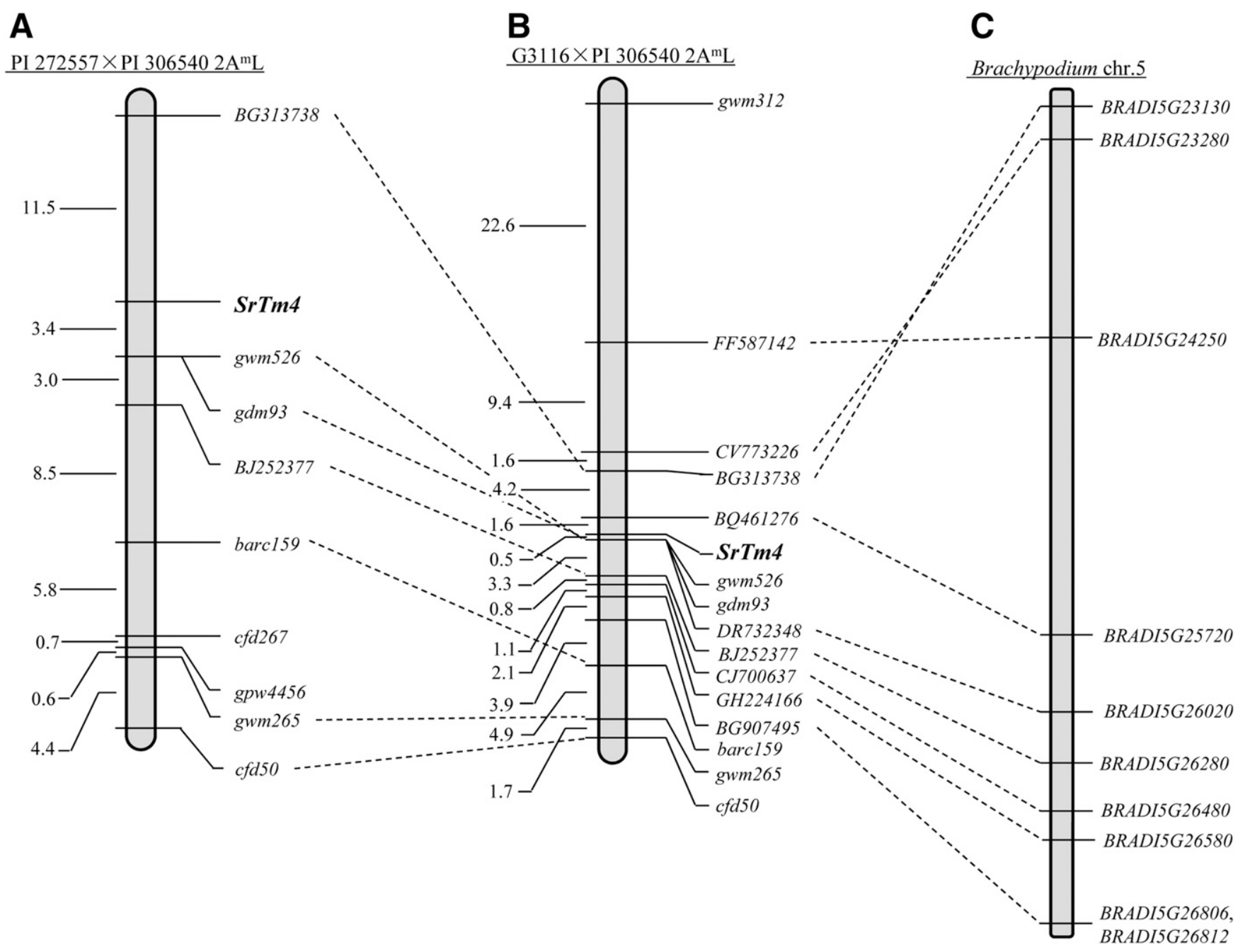

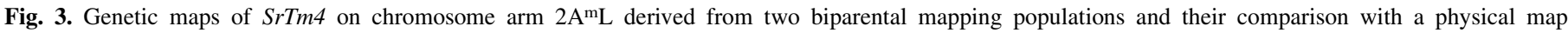

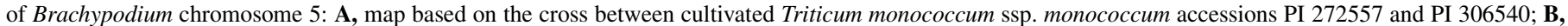

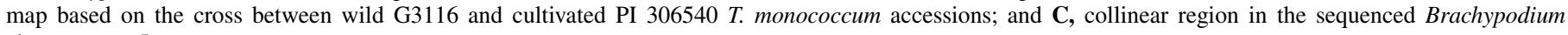
chromosome 5 .

TABLE 2. Primer sequences, annealing temperatures, and restriction enzymes used for markers in the $S r T m 4$ region ${ }^{\mathrm{a}}$

\begin{tabular}{|c|c|c|c|c|c|}
\hline Markers & Marker type & Forward primer $\left(5^{\prime}-3^{\prime}\right)$ & Reverse primer $\left(5^{\prime}-3^{\prime}\right)$ & Restriction enzyme & $\begin{array}{c}\text { Annealing } \\
\text { temperature }\left({ }^{\circ} \mathrm{C}\right)\end{array}$ \\
\hline gwm312 & SSR & ATCGCATGATGCACGTAGAG & ACATGCATGCCTACCTAATGG & - & 56 \\
\hline gwm526 & SSR & CAATAGTTCTGTGAGAGCTGCG & CCAACCCAAATACACATTCTCA & - & 55 \\
\hline gdm93 & SSR & AAAAGCTGCTGGAGCATACA & GGAGCATGGCTACATCCTTC & - & 55 \\
\hline barc 159 & SSR & CGCAATTTATTATCGGTTTTAGGAA & CGCCCGATAGTTTTTCTAATTTCTGA & - & 50 \\
\hline$g w m 265$ & SSR & TGTTGCGGATGGTCACTATT & GAGTACACATTTGGCCTCTGC & - & 55 \\
\hline gpw4456 & SSR & ATTAGTCTCCTCCTCCCTTTGG & AGTAGCCGGGGCAGAAATAG & - & 60 \\
\hline$c f d 267$ & SSR & GTGCGTCGTGTAGCAGCTC & CTCTCTGTCGTCCAGGTCGT & - & 60 \\
\hline cfd 50 & SSR & TTCTGCAACATTTTGTCCCA & CGTATGATCCTAACGAGGGC & - & 60 \\
\hline FF587142 & Indel & TGGAGAAGGTTACGAGGAACGC & TTATGGGCTGTTAATGGGCAAA & - & 59 \\
\hline$C V 773226$ & CAP & AGGTGCCCTGAGCAGCGAGAC & GCCATGTCCTTGCCGTAGCG & ApoI & 56 \\
\hline$B G 313738$ & CAP & CTGACTGCGCCTTATGTTGA & GTGCCCATGGCTTGATGGAGCCG & SacII & 56 \\
\hline$B Q 461276$ & Indel & GAGGAAACTTCAATGTGGC & CAGTAATGCTTATCGGGTAAC & - & 50 \\
\hline$D R 732348$ & CAP & TGAGACCATTCTACAGCGG & TCTTCATCATTTTGGACACCT & AccI & 54 \\
\hline BJ252377 & Indel & ATCAGGGTAATCCCCAAGA & TTCAGAAATCAGATCAACAAGAC & - & 50 \\
\hline CJ700637 & CAP & CACCACCATCCAATCCTAC & CTTCATCACCCGAGACAAC & BsgI & 54 \\
\hline GH224166 & CAP & AATTGTTTGTTCTGCTAGAC & AAATCACTGAAAGTCTTCTG & Fok $\mathrm{I}$ & 48 \\
\hline$B G 907495$ & Indel & AAAGAAAGTTGTGCAGCAAA & TGTCATAGAGTTCAAACAGTGG & - & 51 \\
\hline
\end{tabular}

a SSR, simple sequence repeat; CAP, cleavage amplification polymorphism; Indel, insertion/deletion. 
However, $P$. graminis f. sp. tritici isolates used to map $\mathrm{Sr} 48$ do not possess comparable virulence to those used in this study or previously by Rouse et al. (2011). Therefore, further screening with $P$. graminis f. sp. tritici isolates covering a broad range of virulence phenotypes or a more precise map of $\mathrm{Sr} 48$ sharing common markers with the SrTm4 map will be necessary to determine if $\mathrm{SrTm} 4$ and $\mathrm{Sr} 48$ are different genes or different alleles of the same gene. Once SrTm4 is transferred to hexaploid wheat, a direct allelism test in a $p h l b$ background may provide a definitive answer to this question.

The fourth resistance gene from T. monococcum, $\operatorname{SrTm} 4$, confers resistance to diverse isolates of $P$. graminis $\mathrm{f}$. sp. tritici and is an interesting target to be combined with other Ug99 effective stem rust resistance genes. Pyramids of broadly effective resistance genes are expected to confer more durable resistance, but only the test of time will confirm or reject this hypothesis. Since $\operatorname{SrTm} 4$ and $\mathrm{Sr} 21$ are on the same chromosome arm, it should be possible to introgress both genes simultaneously in hexaploid wheat. However, additional studies will be required to test if the large T. monococcum segment required to introgress both $T$. monococcum genes carries any detrimental gene to hexaploid or tetraploid wheat agronomic performance or quality. If $\mathrm{SrTm} 4$ and $\mathrm{Sr} 48$ are different genes, coupling both genes on chromosome arm $2 \mathrm{AL}$ should also be possible.
The two stem rust resistance genes cloned so far (Periyannan et al. 2013; Saintenac et al. 2013) are NB-LRR, and both confer resistance to $\mathrm{Ug} 99$ with dominant inheritance. The recessive nature of SrTm4 and the mesothetic IT may be indicative of a different resistance mechanism, providing an additional incentive for the cloning of this gene. The absence of NB-LRR genes in the colinear region of Brachypodium provides indirect support for this hypothesis. However, the final identification of the SrTm4 gene will be required to fully test this hypothesis.

The use of two diploid wheat populations with contrasting levels of polymorphism seems to be a viable strategy to clone this resistance gene. The more polymorphic cross between wild and cultivated T. monococcum can be used to rapidly develop markers in the initial stages of the high density mapping (as demonstrated in this study), whereas the cross between the two cultivated T. monococcum accessions can be used in the later stages of the project to identify the causal polymorphisms. A similar strategy was used successfully to clone the Ug99 resistance gene $\mathrm{Sr} 35$ (Saintenac et al. 2013). The cloning of SrTm4 will add additional tools to generate cisgenic resistance cassettes that can combine different resistance genes (e.g., Sr33 and Sr35). In the meantime, the closely linked markers to SrTm4 identified in this study will be useful tools to initiate the introgression of this gene into polyploid wheat and to deploy the natural $\operatorname{SrTm} 4$ allele in wheat commercial varieties.

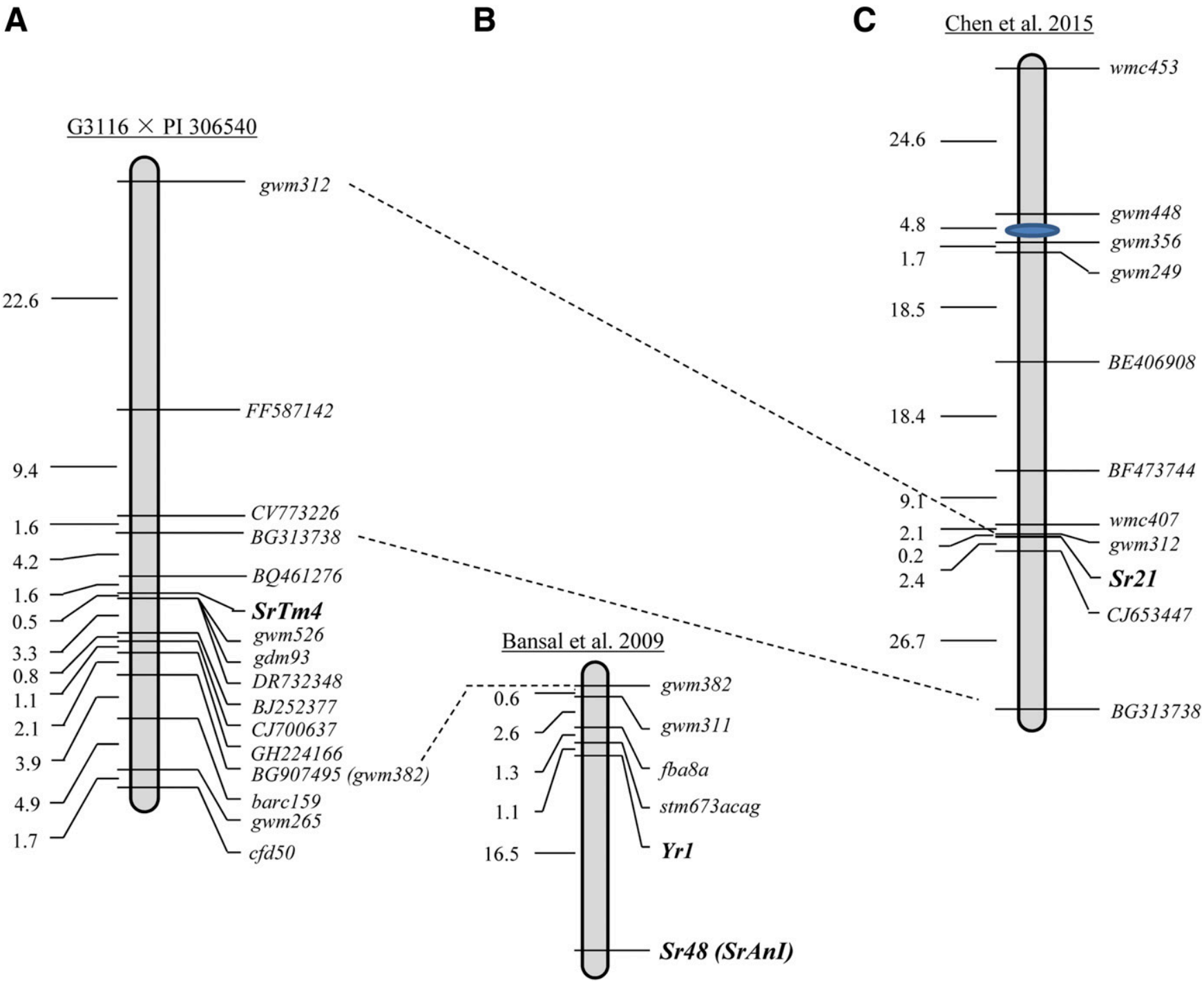

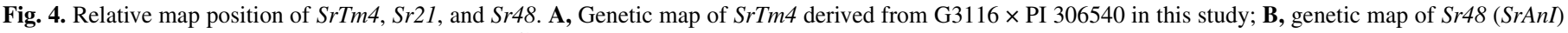
from hexaploid wheat 2A (Bansal et al. 2009); and C, genetic map of Sr21 from Triticum monococcum (Chen et al. 2015). 


\section{ACKNOWLEDGMENTS}

This research was supported by the USDA-ARS National Plant Disease Recovery System, the Durable Rust Resistance in Wheat project administrated by Cornell University and funded by the Bill and Melinda Gates Foundation, and the United Kingdom Department for International Development. J. Dubcovsky acknowledges support from the National Research Initiative Competitive Grants 2011-68002-30029 (TriticeaeCAP) and 2012-67013-19401 from the United States Department of Agriculture (USDA) National Institute of Food and Agriculture (NIFA), and by the Howard Hughes Medical Institute and the Gordon and Betty Moore Foundation. We acknowledge the Computational Genetics Laboratory of the University of Minnesota Supercomputing Institute for computational support. Mention of trademark, proprietary product, or vendor does not constitute a guarantee or warranty of the product by the USDA, and does not imply its approval to the exclusion of other products and vendors that might also be suitable.

\section{LITERATURE CITED}

Bansal, U. K., Bossolini, E., Miah, H., Keller, B., Park, R. F., and Bariana, H. S. 2008. Genetic mapping of seedling and adult plant stem rust resistance in two European winter wheat cultivars. Euphytica 164:821-828.

Bansal, U. K., Hayden, M. J., Keller, B., Wellings, C. R., Park, R. F., and Bariana, H. S. 2009. Relationship between wheat rust resistance genes $\mathrm{Yrl}$ and $\mathrm{Sr} 48$ and a microsatellite marker. Plant Pathol. 58:1039-1043.

Chen, S., Rouse, M. N., Zhang, W., Jin, Y., Akhunov, E., Wei, Y., and Dubcovsky, J. 2015. Fine mapping and characterization of $\mathrm{Sr} 21$, a temperature-sensitive diploid wheat resistance gene effective against the Puccinia graminis f. sp. tritici Ug99 race group. Theor. Appl. Genet. 128:645-656.

Dubcovsky, J., Luo, M., and Dvorak, J. 1995. Differentiation between homoeologous chromosomes $1 \mathrm{~A}$ of wheat and $1 \mathrm{~A}^{\mathrm{m}}$ of Triticum monococcum and its recognition by the wheat Phl locus. Proc. Natl. Acad. Sci. 92:6645-6649.

Dubcovsky, J., Luo, M.-C., Zhong, G.-Y., Bransteiter, R., Desai, A., Kilian, A., Kleinhofs, A., and Dvorak, J. 1996. Genetic map of diploid wheat, Triticum monococcum L., and its comparison with maps of Hordeum vulgare $\mathrm{L}$. Genetics 143:983-999.

Dvorak, J. 1976. The relationship between the genome of Triticum urartu and the A and B genomes of Triticum aestivum. Can. J. Genet. Cytol. 18: 371-377.

Dyck, P. L. 1992. Transfer of a gene for stem rust resistance from Triticum araraticum to hexaploid wheat. Genome 35:788-792.

FAO. 2013. Wheat-world yield totals. Online Publication. http://faostat3.fao. org/faostat-gateway/go/to/download/Q/QC/E

Faris, J. D., Xu, S. S., Cai, X., Friesen, T. L., and Jin, Y. 2008. Molecular and cytogenetic characterization of a durum wheat-Aegilops speltoides chromosome translocation conferring resistance to stem rust. Chromosome Res. 16:1097-1105.

Gerechter-Amitai, Z. K., Wahl, I., Vardi, A., and Zohary, D. 1971. Transfer of stem rust seedling resistance from wild diploid einkorn to tetraploid durum wheat by means of a triploid hybrid bridge. Euphytica 2:281-285.

Giorgi, B., and Bozzini, A. 1969. Karyotype analysis in Triticum I. Analysis of Triticum turgidum (L.) Thell. and some related tetraploid wheats. Caryologia 22:249-258.

Jin, Y., and Singh, R. P. 2006. Resistance in U.S. wheat to recent Eastern African isolates of Puccinia graminis f. sp. tritici with virulence to resistance gene Sr31. Plant Dis. 90:476-480.

Jin, Y., Szabo, L. J., Pretorius, Z. A., Singh, R. P., Ward, R., and Fetch, T., Jr. 2008. Detection of virulence to resistance gene $\mathrm{Sr} 24$ within race TTKS of Puccinia graminis f. sp. tritici. Plant Dis. 92:923-926.

Jin, Y., Szabo, L. J., Rouse, M. N., Fetch, T., Jr., Pretorius, Z. A., Wanyera, R., and Njau, P. 2009. Detection of virulence to resistance gene Sr36 within the TTKS race lineage of Puccinia graminis f. sp. tritici. Plant Dis. 93:367-370.

Johnson, B. L., and Dhaliwal, H. S. 1976. Reproductive isolation of Triticum boeticum and Triticum urartu and the origin of the tetraploid wheats. Am. J. Bot. 63:1088-1094.

Kerber, E. R., and Dyck, P. L. 1979. Resistance to stem and leaf rust of wheat in Aegilops squarrosa and transfer of a gene for stem rust resistance to hexaploid wheat. Proc. 5th International Wheat Genetics Symposium, New Delhi, India.

Kerber, E. R., and Dyck, P. L. 1990. Transfer to hexaploid wheat of linked genes for adult-plant leaf rust and seedling stem rust resistance from amphiploid of Aegilops speltoides $\times$ Triticum monococcum. Genome 33: 530-537.

Lander, E. S., Green, P., Abrahamson, J., Barlow, A., Daly, M. J., Lincoln, S. E., and Newburg, L. 1987. MAPMAKER: An interactive computer package for constructing primary genetic linkage maps of experimental and natural populations. Genomics 1:174-181.

Leonard, K. J. 2001. Stem rust: future enemy? Pages 119-146 in: Stem Rust of Wheat: From Ancient Enemy to Modern Foe. P. D. Peterson, ed. American Phytopathological Society, St. Paul, MN.

Liu, R., and Meng, J. 2003. MapDraw: A Microsoft Excel macro for drawing genetic linkage maps based on given genetic linkage data. Hereditas 25: 317-321.

Luo, M.-C., Dubcovsky, J., and Dvorak, J. 1996. Recognition of homology by the wheat Phl locus. Genetics 144:1195-1203.

Marais, G. F., Wessels, W. G., Horn, M., and du Toit, F. 1998. Association of a stem rust resistance gene (Sr45) and two Russian wheat aphid resistance genes ( $D n 5$ and $D n 7$ ) with mapped structural loci in common wheat. S. Afr. J. Plant Soil 15:67-71.

McIntosh, R. A., Dyck, P. L., The, T. T., Cusick, J., and Milne, D. L. 1984. Cytogenetical studies in wheat. XIII. Sr35-a 3rd gene from Triticum monococcum for resistance to Puccinia graminis tritici. Zeit. Pflaz. 92:1-14.

McIntosh, R. A., and Gyarfas, J. 1971. Triticum timopheevi as a source of resistance to wheat stem rust. Zeit. Pflaz. 66:240-248.

McIntosh, R. A., Wellings, C. R., and Park, R. F. 1995. Wheat Rusts: An Atlas of Resistance Genes. CSIRO Publications, East Melbourne, Australia.

McIntosh, R. A., Yamazaki, Y., Dubcovsky, J., Rogers, J., Morris, C., Appels, R., and Xia, X. C. 2013. Catalogue of gene symbols for wheat. http://www. shigen.nig.ac.jp/wheat/komugi/genes/macgene/2013/GeneSymbol.pdf

Nath, J., Hanzel, J. J., Thompson, J. P., and McNay, J. W. 1984. Additional evidence implicating Triticum searsii as the B-genome donor to wheat. Biochem. Genet. 22:37-50.

Olson, E. L., Rouse, M. N., Pumphrey, M. O., Bowden, R. L., Gill, B. S., and Poland, J. A. 2013a. Simultaneous transfer, introgression, and genomic localization of genes for resistance to stem rust race TTKSK (Ug99) from Aegilops tauschii to wheat. Theor. Appl. Genet. 126:1179-1188.

Olson, E. L., Rouse, M. N., Pumphrey, M. O., Bowden, R. L., Gill, B. S., and Poland, J. A. 2013b. Introgression of stem rust resistance genes SrTA10187 and SrTA10171 from Aegilops tauschii to wheat. Theor. Appl. Genet. 126: 2477-2484.

Periyannan, S., Moore, J., Ayliffe, M., Bansal, U., Wang, X., Deal, K., Luo, M., Kong, X., Bariana, H., Mago, R., McIntosh, R., Dodds, P., Dvorak, J., and Lagudah, E. 2013. The gene Sr33, an ortholog of barley Mla genes, encodes resistance to wheat stem rust race Ug99. Science 341:786-788.

Periyannan, S. K., Bansal, U. K., and Bariana, H. S. 2011. A robust molecular marker for the detection of shortened introgressed segment carrying the stem rust resistance gene $S r 22$ in common wheat. Theor. Appl. Genet. 122: $1-7$.

Peterson, P. D., Leonard, K. J., Roelfs, A. P., and Sutton, T. B. 2005. Effect of barberry eradication on changes in populations of Puccinia graminis in Minnesota. Plant Dis. 89:935-940.

Pretorius, Z. A., Singh, R. P., Wagoire, W. W., and Payne, T. S. 2000. Detection of virulence to wheat stem rust resistance gene Sr31 in Puccinia graminis f. sp. tritici in Uganda. Plant Dis. 84:203.

Pretorius, Z. A., Szabo, L. J., Boshoff, W. H. P., Herselman, L., and Visser, B. 2012. First report of a new TTKSF race of wheat stem rust (Puccinia graminis f. sp. tritici) in South Africa and Zimbabwe. Plant Dis. 96:590.

Röder, M. S., Korzun, V., and Wendehake, K. 1998. A microsatellite map of wheat. Genetics 149:2007-2023.

Roelfs, A. P. 1978. Estimated losses caused by rust in small grain cereals in the United States-1918-76. U.S. Dept. Agric. Agric. Res. Serv., Misc. Publ. 1363.

Roelfs, A. P. 1982. Effects of barberry eradication on stem rust in the United States. Plant Dis. 66:177-181.

Roelfs, A. P. 1985. Wheat and rye stem rust. Pages 22-29 in: The Cereal Rusts Vol. II; Diseases, Distribution, Epidemiology, and Control. A. P. Roelfs and W. R. Bushnell, eds. Academic Press Inc., Orlando, FL.

Rouse, M. N., and Jin, Y. 2011a. Genetics of resistance to race TTKSK of Puccinia graminis f. sp. tritici in Triticum monococcum. Phytopathology 101:1418-1423.

Rouse, M. N., and Jin, Y. 2011b. Stem rust resistance in A-genome diploid relatives of wheat. Plant Dis. 95:941-944.

Rouse, M. N., Nirmala, J., Jin, Y., Chao, S., Fetch, T. G., Jr., Pretorius, Z. A., and Hiebert, C. W. 2014. Characterization of $S r 9 h$, a wheat stem rust resistance allele effective to Ug99. Theor. Appl. Genet. 127:1681-1688.

Rouse, M. N., Wanyera, R., Njau, P., and Jin, Y. 2011. Sources of resistance to stem rust race Ug99 in spring wheat germplasm. Plant Dis. 95:762-766.

Saintenac, C., Zhang, W., Salcedo, A., Rouse, M. N., Trick, H. N., Akhunov, E., and Dubcovsky, J. 2013. Identification of wheat gene Sr35 that confers resistance to Ug99 stem rust race group. Science 341:783-786.

Sharma, R. K., Singh, P. K., Vinod, Joshi, A. K., Bhardwaj, S. C., Bains, N. S., and Singh, S. 2013. Protecting South Asian wheat production from stem rust (Ug99) epidemic. J. Phytopathol. 161:299-307. 
Singh, R. P., Hodson, D. P., Huerta-Espino, J., Jin, Y., Bhavani, S., Njau, P., Herrera-Foessel, S., Singh, P. K., Singh, S., and Govinda, V. 2011. The emergence of Ug99 races of stem rust fungus is a threat to world wheat production. Annu. Rev. Phytopathol. 49:465-481.

Somers, D. J., Isaac, P., and Edwards, K. 2004. A high density microsatellite consensus map for bread wheat (Triticum aestivum L.). Theor. Appl. Genet. 109:1105-1114

Song, Q. J., Shi, J. R., Singh, S., Fickus, E. W., Costa, J. M., Lewis, J., Gill, B. S., Ward, R., and Cregan, P. B. 2005. Development and mapping of microsatellite (SSR) markers in wheat. Theor. Appl. Genet. 110:550-560.

Stakman, E. C., Stewart, D. M., and Loegering, W. Q. 1962. Identification of physiological races of Puccinia graminis var. tritici. U.S. Dept. Agric. Agric. Res. Serv. E-617.
The, T. T. 1973. Chromosome location of genes conditioning stem rust resistance transferred from diploid to hexaploid wheat. Nat. New Biol. 241: 256.

The International Wheat Genome Sequencing Consortium (IWGSC). 2014. A chromosome-based draft sequence of the hexaploid bread wheat (Triticum aestivum) genome. Science 345:286-287.

Yu, J. B., Bai, G. H., Zhou, W. C., Dong, Y. H., and Kolb, F. L. 2008. Quantitative trait loci for Fusarium head blight resistance in a recombinant inbred population of Wangshuibai/Wheaton. Phytopathology 98:87-94.

Zhang, W., Olson, E. L., Saintenac, C., Rouse, M., Abate, Z., Jin, Y., Akhunov, E., Pumphrey, M. O., and Dubcovsky, J. 2010. Genetic maps of stem rust resistance gene $\mathrm{Sr} 35$ in diploid and hexaploid wheat. Crop Sci. 50: 2464-2474. 